\title{
EFFECT OF DIFFERENT SURFACE PRETREATMENT METHOD ON VACUUM BRAZING JOINT PROPERTIES OF ALSI50 ALLOY
}

\author{
Zeng Gao* - Jianguang Feng - Xingkong Tao - Fengsong Ma - Jitai Niu
}

School of Materials Science and Engineering, Henan Polytechnic University, Henan, Jiaozuo, 454003, P. R. China

\begin{tabular}{l}
\hline ARTICLE INFO \\
\hline Article history: \\
Received: 4.9 .2018$. \\
Received in revised form: 1.11 .2018$. \\
Accepted: 8.11 .2018$. \\
\hline Keywords: \\
AlSi50 alloy \\
Surface pretreatment \\
Vacuum brazing \\
Microstructure \\
\hline DOI: http://doi.org/10.30765/er.40.3.09
\end{tabular}

\section{Introduction}

At present, high-end equipment manufacturing areas need a lot of new materials, which must have excellent strength, ductility, toughness, corrosion resistance and thermal conductivity [1-4]. Compared with the conventional materials, high-silicon aluminum alloy has excellent performances, such as light weight, high strength, high thermal conductivity, small coefficient of linear expansion, good dimensional stability and so on, which makes this kind of material widely used in the fields of aerospace electronic packaging [5, 6]. At the same time, high-silicon aluminum alloy also can

\begin{abstract}
:
In this paper, the effect of different surface pretreatment method on properties of vacuum brazed joint of AlSi50 alloy was investigated. The surface pretreatment methods of specimen before brazing include sanding, $\mathrm{NaOH}$ corrosion, $\mathrm{HCl}$ corrosion, $\mathrm{H}_{2} \mathrm{SO}_{4}$ corrosion and nickel plating. The experimental results indicate that the width of brazing joint varies with different surface pretreatment methods. The joint with sanding pretreatment, has the largest brazing seam width of $20 \mu \mathrm{m}$. Meanwhile, joint with $\mathrm{H}_{2} \mathrm{SO}_{4}$ corrosion has the narrowest brazing seam width. The brazing filler metal can wet and spread on different pretreated specimen very well. Spectrum analysis indicates that nickel-plate on AlSi50 surface, can interact with brazing filler metal, which increases mechanical property of brazing joint. For brazing of AlSi50 alloy, the optimal pretreatment method is nickel plating. After nickel plating pretreatment, brazing joint has the maximum shear strength 82.05 MPa by using brazing filler metal Al52Cu33-Mg12-Ni3 and following technological parameters: brazing temperature $580^{\circ} \mathrm{C}$, soaking time $30 \mathrm{~min}$ and pressure $3 \mathrm{MPa}$.
\end{abstract}

be plated by copper, nickel and other materials to produce a good plating effect $[7,8]$.

In recent years, researchers have done a lot of research about high-silicon aluminum $[9,11]$. But very little research has been done on its welding technology and property. This makes the welding problem the main factor for the promotion and application of highsilicon aluminum. At present, the welding methods of high-silicon aluminum are mainly solid phase welding and brazing $[12,13]$. High-silicon aluminum is easy to be oxidized at elevated temperature and room temperature to produce refractory alumina film. However, the oxide film seriously affects the welding

${ }^{*}$ Corresponding author.

E-mail address: mrgaozeng@163.com 
process and quality. For further wide application of high-silicon aluminum, an efficient and high-quality welding technology has to be investigated [14]. Vacuum brazing is a kind of precise and effective welding method, which is appropriate for high-silicon aluminum welding since it can provide an oxygen-free environment preventing formation of aluminium oxide. For vacuum brazing, some factors such as brazing temperature, soaking time, pressure on specimen, as well as brazing filler metal have influence on joint performance, and researchers have already done a lot of work in that direction [15]. Besides those factors, the surface pretreatment method of specimen before brazing has also significant influence on joint performance [16-18]. In this paper, the effects of different surface pretreatment methods on performance of vacuum brazing joint are discussed in detail.

\section{Experiment material and procedure}

The base material used in this experiment is AlSi50 alloy manufactured by pressure casting. The chemical composition, performance and microstructure of AlSi50 are shown in Table 1, Table 2 and Figure 1, respectively. Each specimen was cut into dimension of $20 \mathrm{~mm} \times 10 \mathrm{~mm} \times 4 \mathrm{~mm}$. Brazing filler metal used in this research was Al52-Cu33Mg12-Ni3, which was prepared by melt-spinning technology and proved to be an applicable filler metal for AlSi50 alloy joining by previous research [19].

Table 1. Chemical composition of AlSi50 (wt\%)

\begin{tabular}{|c|c|c|c|c|}
\hline Element & $\mathrm{Si}$ & $\mathrm{Fe}$ & $\mathrm{Zn}$ & $\mathrm{Ca}$ \\
\hline Content & 50.6 & 0.02 & 0.015 & 0.01 \\
\hline Element & $\mathrm{Sn}$ & $\mathrm{Pb}$ & $\mathrm{Al}$ & \\
\hline Content & 0.015 & 0.015 & Balance & \\
\hline
\end{tabular}

Table 2. Physical and mechanical performance of AlSi50

\begin{tabular}{|c|c|c|c|}
\hline $\begin{array}{c}\text { Thermal } \\
\text { expansivity } \\
\left(\mathrm{ppm} /{ }^{\circ} \mathrm{C}\right)\end{array}$ & $\begin{array}{c}\text { Thermal } \\
\text { conductivity } \\
(\mathrm{W} / \mathrm{mK})\end{array}$ & $\begin{array}{c}\text { Density } \\
\left(\mathrm{g} / \mathrm{cm}^{3}\right)\end{array}$ & $\begin{array}{c}\text { Tensile } \\
\text { strength } \\
(\mathrm{MPa})\end{array}$ \\
\hline 11.5 & 140 & 2.5 & 220 \\
\hline $\begin{array}{c}\text { Yield } \\
\text { strength } \\
(\mathrm{MPa})\end{array}$ & Poisson ratio & Elongation & $\begin{array}{c}\text { Elasticity } \\
\text { modulus } \\
(\mathrm{GPa})\end{array}$ \\
\hline 210 & 0.25 & $<1$ & 105 \\
\hline
\end{tabular}
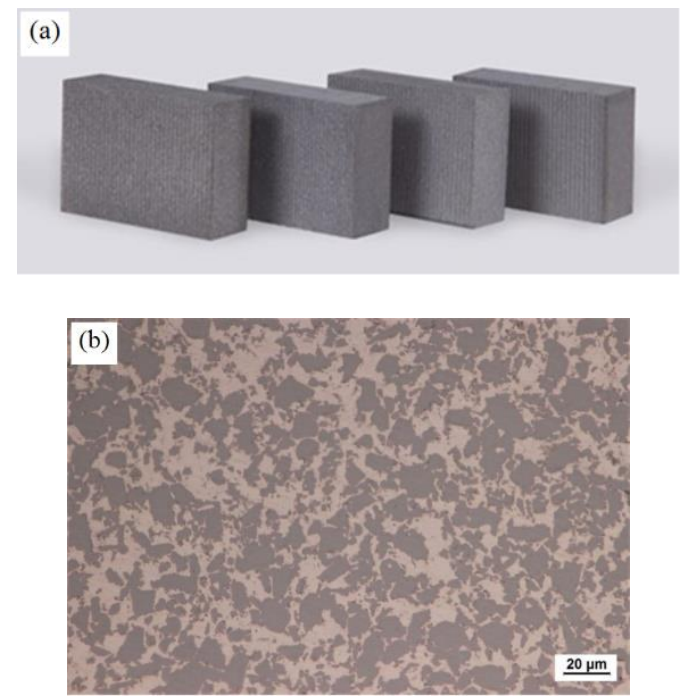

Figure 1. AlSi50 alloy: (a) macrospecimen and (b) microstructure

Vacuum brazing experiment was performed on OTL1200 vacuum tube furnace. The process parameters were set as following in experiment: the vacuum degree $6.5 \times 10^{-3} \mathrm{~Pa}$, brazing temperature $580{ }^{\circ} \mathrm{C}$, soaking time $30 \mathrm{~min}$ and welding pressure 3 $\mathrm{MPa}$. Before vacuum brazing, AlSi50 surface was pretreated by five different methods: sanding with \#120 paper, $\mathrm{H}_{2} \mathrm{SO}_{4}$ corrosion $(0.3 \mathrm{~mol} / \mathrm{L}$ and etching time 30 seconds), $\mathrm{HCl}$ corrosion $(0.3 \mathrm{~mol} / \mathrm{L}$ and etching time 30 seconds), $\mathrm{NaOH}$ corrosion (0.3 $\mathrm{mol} / \mathrm{L}$ and etching time 30 seconds) and nickel plating (electroless plating). In order to study the effect of surface pretreatment on joint properties, vacuum brazing was also performed on a nonpretreated AlSi50 specimen with the same process parameters. A specific specimen number and pretreatment method is presented in Table 3.

Table 3. Different surface pretreatment method of specimen

\begin{tabular}{cccc}
\hline $\begin{array}{c}\text { Specimen } \\
\text { number }\end{array}$ & $\begin{array}{c}\text { Surface } \\
\text { pretreatment } \\
\text { method }\end{array}$ & $\begin{array}{c}\text { Specimen } \\
\text { number }\end{array}$ & $\begin{array}{c}\text { Surface } \\
\text { pretreatment } \\
\text { method }\end{array}$ \\
\hline $1 \#$ & $\begin{array}{c}\text { Sandpaper } \\
\text { polished } \\
\text { NaOH } \\
\text { corrosion }\end{array}$ & $4 \#$ & $\begin{array}{c}\mathrm{H}_{2} \mathrm{SO}_{4} \\
\text { corrosion } \\
\text { Nickel } \\
\text { plating }\end{array}$ \\
$3 \#$ & $\mathrm{HCl}$ corrosion & - & - \\
\hline
\end{tabular}



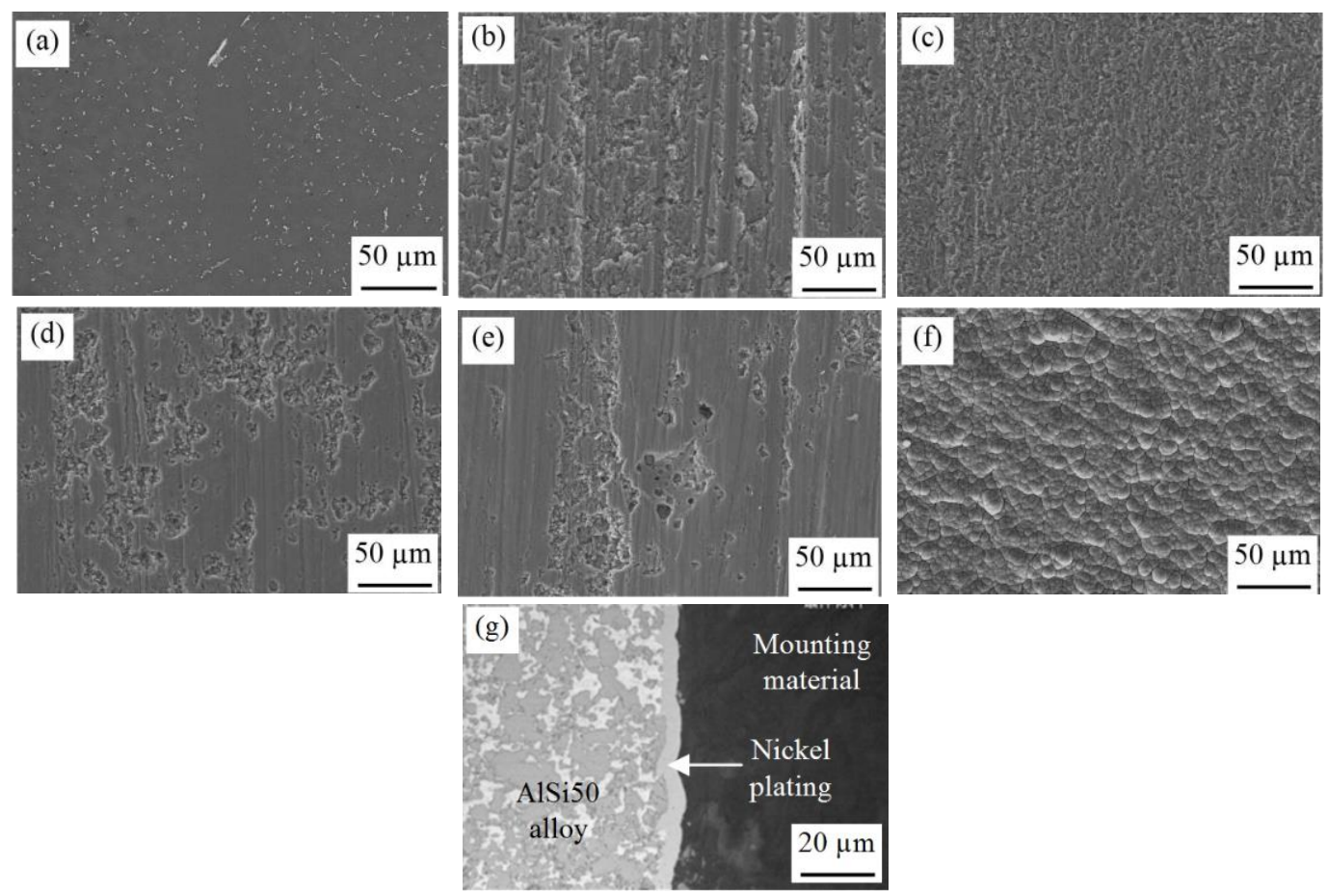

Figure 2. Surface microstructure of specimen after different pretreatments: (a) Non-pretreatment, (b) Sanding with \#12O paper, (c) NaOH corrosion, (d) $\mathrm{HCl}$ corrosion, (e) $\mathrm{H}_{2} \mathrm{SO}_{4}$ corrosion, (f) Nickel plating and $(\mathrm{g})$ Nickel plating cutting from the cross section

Microstructure of the specimen was analyzed by optical metallographic microscope OLYMPUS CK40M, and the shear strength was tested on electronic universal testing machine CMT5105. Joint morphologies were observed by Merlin Compact scanning electron microscopy and local analysis was performed on OXFOED spectroscopy.

\section{Results and discussions}

\subsection{Surface microstructure of specimen after different surface pretreatment}

Figure 2 shows surface microstructure of the specimen after different surface pretreatments.

Figure 2 (a) shows the surface microstructure of AlSi50 alloy without pretreatment. It can be seen that AlSi50 alloy is free from the brazing defects such as void. Meanwhile, Si particles distribute uniformly on $\mathrm{Al}$ matrix. Figure 2 (b) presents a groove-like surface morphology after sanding with \#120 paper. Theoretically, grooves on AlSi50 surface will benefit joint brazing performance because it will lead the filler metal to the faying surface effectively. Figure 2 (c), Figure 2 (d) and Figure 2(e) present surface morphologies of AlSi50 after corrosion with $\mathrm{NaOH}$, $\mathrm{HCl}$ and $\mathrm{H}_{2} \mathrm{SO}_{4}$, respectively. The oxide on AlSi50 surface is removed during the corrosion. Figure 2 (f) shows that AlSi50 surface is covered by defect-free nickel plating totally. Figure 2 (g) shows the microstructure of nickel-plating specimen cutting from the cross section. It can be seen that the nickelplate on AlSi50 is very well with the thickness around $10 \mu \mathrm{m}$. Theoretically, nickel plating on AlSi50 surface will improve joint performance because it can change joint status. Before nickel plating, two kinds of bonding interfaces exist in brazing seam: interface between filler metal and aluminum, interface between filler metal and Si particle. However, the strength of interface between filler metal and $\mathrm{Si}$ particle is quite weak. After the nickel plating, the weak combination between filler metal and $\mathrm{Si}$ particle will be replaced by the nickel.

\subsection{Microstructure of vacuum brazed joint}

Figure 3 shows microstructure of brazed joints. As can be seen, the combinations between brazing filler metal and base metal with different surface states are all quite well. The reason for that is that the base material and brazing filler metal have the same matrix element aluminum. Therefore, the defects in joint such as pore, unwetted area, slag inclusion and so on have not appeared. As presented in Figure 3 (a), 
joint has the largest brazing seam width of $20 \mu \mathrm{m}$ due to the existence of groove produced during sanding process. From Figure 3 (b) to Figure 3(d), joint width decreases gradually due to the increasing of solution's acidity. In all of the pretreatment solutions, $\mathrm{H}_{2} \mathrm{SO}_{4}$ has the strongest acidity and it can quickly destroy alumina on AiSi50 surface as well as aluminum in matrix. Hence, more silicon phase exposed to AlSi50 surfacewill promote cross-link in joint and narrow the joint, as shown in Figure 3(d). Figure 3 (e) shows some black particles appear in brazed joint. The EDS analysis indicates that black particles are mainly composed of phosphorous compound. Brazing filler metal can wet nickel-plate very well. Basically, the specimen after nickel plating and the specimen after $\mathrm{NaOH}$ corrosion have the same joint width.

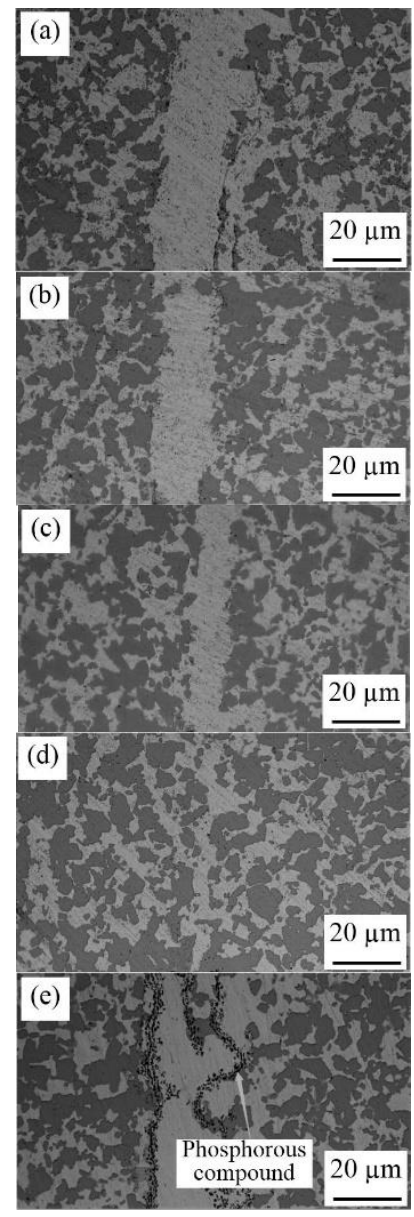

Figure 3. Metallographic photograph of vacuum brazed joint after different surface pretreatment: (a) Sanding with \#120 paper, (b) $\mathrm{NaOH}$ corrosion, (c) $\mathrm{HCl}$ corrosion, (d) $\mathrm{H}_{2} \mathrm{SO}_{4}$ corrosion, (e) Nickel plating

\subsection{Effect of surface pretreatment methods on mechanical properties of the brazed joints}

Using $\mathrm{Al}_{52}-\mathrm{Cu}_{33}-\mathrm{Mg}_{12}-\mathrm{Ni}_{3}$ foil as filler metal, the shear strengths of brazed joints are quite different with different surface condition of specimen, as seen in Figure 4.

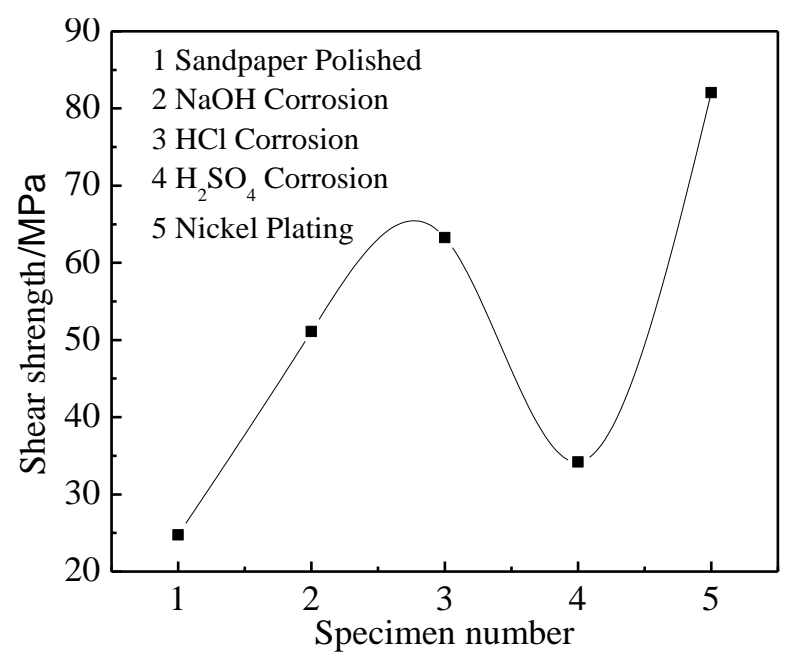

Figure 4. Relationship between joint shear strength and surface pretreatment methods

Figure 4 presents joint shear strength of AlSi50 after sanding with \#120 paper has only $24.76 \mathrm{MPa}$. Though grooves on surface can promote wetting behavior of brazing filler metal, the micro grooves in joint reduce bonding performance. The joint shear strength of AlSi50 after $\mathrm{HCl}$ corrosion has a relatively high value of $63.28 \mathrm{MPa}$ compared with the specimen after $\mathrm{NaOH}$ corrosion and $\mathrm{H}_{2} \mathrm{SO}_{4}$ corrosion. The reason for that is $\mathrm{HCl}$ solution can get rid of alumina film but not so strong to break aluminum matrix. The joint shear strength of AlSi50 after nickel plating achieves the maximum value of 82.05 MPa as can be seen in Figure 4. It indicates that bonding force between brazing filler metal and nickel-plate is much higher than that between brazing filler metal and AlSi50. The nickel-plate can improve joint mechanical property significantly.

\subsection{Spectrum analysis}

Mechanical analysis indicates that the specimen with nickel plating has the largest shear strength. In this research, the spectrum analysis mainly focuses on nickel plating specimen. Figure 5 shows SEM image of the brazed joint. 

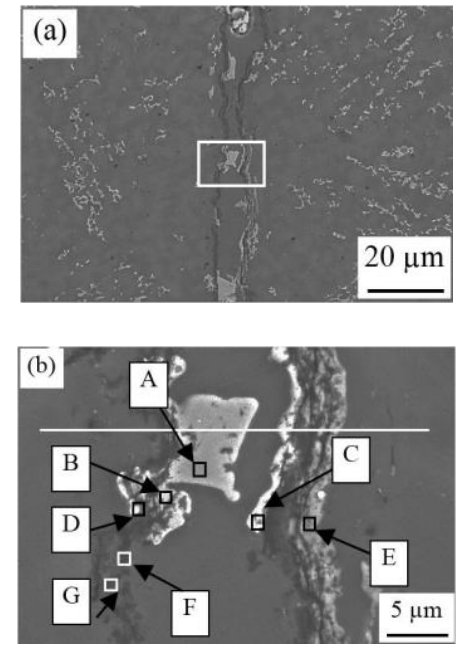

Figure 5. SEM image of brazed joint pretreated by nickel plating: (a) joint appearance and $(b)$ zoom in at the white area

Figure 5 (a) shows that nickel plate on $\mathrm{AlSi} 50$ is quite uniformed. The nickel plate will eliminate the weak connection such as silicon particle-particle connection. That will be very helpful for the increasing of joint strength. Interaction at interface between filler metal and base material is a very important factor for brazing. As shown in Figure 5 (b), interaction occurred between filler metal and nickel plating. In order to study the interaction in joint, the EDS analysis was performed in several places as defined in Figure 5 (b). The EDS results can be found in Table 4 .

Table 4. The EDS results at defined places

\begin{tabular}{ccccccc}
\hline Region & $\mathrm{C}$ & $\mathrm{O}$ & $\mathrm{Al}$ & $\mathrm{P}$ & $\mathrm{Ni}$ & margin \\
\hline $\mathrm{A}$ & 2.26 & 0.00 & 51.89 & 0.00 & 38.48 & 0.00 \\
$\mathrm{~B}$ & 7.54 & 6.74 & 53.48 & 0.62 & 30.45 & 0.00 \\
$\mathrm{C}$ & 0.00 & 12.69 & 55.72 & 4.06 & 26.19 & 0.00 \\
$\mathrm{D}$ & 13.36 & 6.98 & 52.22 & 0.98 & 24.08 & 0.00 \\
$\mathrm{E}$ & 11.57 & 5.46 & 60.74 & 1.82 & 16.08 & 3.51 \\
$\mathrm{~F}$ & 6.46 & 29.73 & 59.74 & 3.52 & 0.00 & \\
$\mathrm{G}$ & 23.29 & 24.78 & 47.32 & 2.16 & 0.00 & \\
\hline
\end{tabular}

Light white region such as regain $\mathrm{A}, \mathrm{B}, \mathrm{C}$ and $\mathrm{D}$, mainly compose of $\mathrm{Al}$ and $\mathrm{Ni}$, which means nickelplate on AlSi50 surface, interacts with the filler metal during brazing effectively formed intermetallic compound of $\mathrm{Al}$ and $\mathrm{Ni}$ such as $\mathrm{Al}_{3} \mathrm{Ni}$ and $\mathrm{Al}_{3} \mathrm{Ni}_{2}$. The interaction between nickel plating and filler metal will increase mechanical property of the joint, as can be seen in shear strength test.

\section{Conclusion}

With different surface pretreatment methods, AlSi50 alloy was brazed together using vacuum brazing technology and $\mathrm{Al}_{52}-\mathrm{Cu}_{33}-\mathrm{Mg}_{12}-\mathrm{Ni}_{3}$ foil as filler metal. Based on this research, the following conclusions can be drawn:

(1) The width of brazing joint varies with different surface pretreatment methods. The joint with sanding pretreatment, has the largest brazing seam width of $20 \mu \mathrm{m}$. Meanwhile, the joint with $\mathrm{H}_{2} \mathrm{SO}_{4}$ corrosion has the narrowest brazing seam width, which can not be found nearly in light microscope.

(2) Nickel-plate on AlSi50 surface, can interact with the filler metal during brazing effectively, which increases mechanical property of the brazing joint.

(3) For brazing of AlSi50 alloy, the optimal pretreatment method is nickel plating. After the nickel plating pretreatment, brazing joint has the maximum shear strength $82.05 \mathrm{MPa}$ with the following technological parameters: brazing temperature $580{ }^{\circ} \mathrm{C}$, soaking time $30 \mathrm{~min}$ and pressure $3 \mathrm{MPa}$.

\section{Acknowledgments}

This research was supported by the National Natural Science Foundation of China under grant no. 51245008 and the Henan Provincial Science and Technology Project of China under grant no. 182102210312.

\section{References}

[1] Zhang, K., He, X., Wang, Z., Liu, X.: Application of silicon-aluminum alloy welding technology in space camera, Infrared, 36(2015), 10, 9-13.

[2] Chen, Z., Li, C., Xu, L., Mi, G., Hu, Y.: Research on the grinding performance of high pressure sintering SiCp/Al matrix composites, Engineering Review, 38(2018), 2, 175-181.

[3] Rajani, H., Phillion, A.: A mesoscale solidification simulation of fusion welding in aluminum-magnesium-silicon alloys, Acta Materialia, 77(2014), 4, 162-172.

[4] Gao, Z., Feng, J., Yang, H., Pakkanen, J., Niu, $\mathrm{J} .:$ Friction stir welding of new electronic packaging materials SiCp/Al composite with Tjoint, Engineering Review, 38(2018), 3, 352359. 
[5] Zhang, L., Gan, G., Yang, B.: Microstructure and property measurements on in situ TiB2/70Si-Al composite for electronic packaging applications, Materials and Design, 36(2012), 177-181.

[6] Rao, A., Bale, H., Merkle, A., Deshmukh, V.: $3 D$ investigation of the microstructure evolution in hypereutectic aluminum silicon alloy using high resolution phase contrast $X$-ray microscopy, Microscopy \& Microanalysis, 22(2016), 1890-1891.

[7] Jae, G., Tae, Y., Young, H., Su, H., Jung, M.: Synergistic effect of ultrasonic melt treatment and fast cooling on the refinement of primary $\mathrm{Si}$ in a hypereutectic Al-Si alloy, Acta Materialia, 14(2018), 31-40.

[8] Zhou, M., Lei, D., Li, Z.: Analysis on the defects and mechanism of laser seal welding of high silicon content aluminum alloy shell, ElectroMechanical Engineering, 29(2013), 6, 54-56.

[9] Zhi, H., Yan, H., Rao, Y.: Effects of samarium addition on microstructure and mechanical properties of as-cast $\mathrm{Al}-\mathrm{Si}$-Cu alloy, Transactions of Nonferrous Metals Society of China, 23(2013), 11, 3228-3234.

[10] Puga, H., Costa, S., Barbosa, J., Ribeiro, S., Prokic, M.: Influence of ultrasonic melt treatment on microstructure and mechanical properties of AlSi9Cu3 alloy, Journal of Materials Processing Technology, 211(2011), 11, 1729-1735.

[11] Chiang, C., Tsao, C.: Si coarsening of sprayformed high loading hypereutectic Al-Si alloys in the semisolid state, Materials Science and
Engineering A, 396(2005), 263-270.

[12] Liu, W., Wang, R., Peng, C., Mo, J.: Research progress of spray deposited high Si-Al alloys for electronic packaging, Chinese Journal of Nonferrous Metals, 22(2012), 12, 3446-3455.

[13] Sasaki, M., Kaminaga, M., Tagami, M.: Influence of copper and silicon contents crack in copper alloyed aluminum silicon alloy using electron beam welding, Journal of the Japan Foundrymens Society, 71(2011), 227-232.

[14] Liu, J., Xu, D., Chen, M.: Present situation and prospect of welding of high silicon aluminum alloy, Modern Welding Technology, 12(2014), 26, 26-29.

[15] Chen, X., Hou, L., Xu, D.: Microstructure and properties testing of hypereutectic Si-Al alloy vacuum brazed joint, Journal of Netshape Forming Engineering, 4(2012), 13-16.

[16] Gao, Z., Xia, R., Qin, S., Mi, G., Niu, J.: Effects of temperature and surface metal plating on vacuum brazing between aluminum alloy matrix composites and kovar alloy, Bulletin of the Chinese Ceramic Society, 36(2017), 1, 13-16.

[17] Chen, X.: The research on continuity test of hypereutectic Al-Si alloy, Thesis, Hefei University of Technology, 2012.

[18] Hou, L.: Investigation on brazing process of new high silicon aluminum alloy, Thesis, Hefei University of Technology, 2012.

[19] Tao, X.: Research on melt brazing process and mechanism of SiCp/6063Al composite and DM305 electronic glass, Thesis, Henan Polytechnic University, 2017. 